\title{
Contribution of human hematopoietic stem cells to liver repair
}

\author{
Ping Zhou • Louisa Wirthlin • Jeannine McGee • \\ Geralyn Annett • Jan Nolta
}

Received: 23 May 2009 / Accepted: 26 May 2009 / Published online: 17 June 2009

(C) The Author(s) 2009. This article is published with open access at Springerlink.com

\begin{abstract}
Immune-deficient mouse models of liver damage allow examination of human stem cell migration to sites of damage and subsequent contribution to repair and survival. In our studies, in the absence of a selective advantage, transplanted human stem cells from adult sources did not robustly become hepatocytes, although some level of fusion or hepatic differentiation was documented. However, injected stem cells did home to the injured liver tissue and release paracrine factors that hastened endogenous repair and enhanced survival. There were significantly higher levels of survival in mice with a toxic liver insult that had been transplanted with human stem cells but not in those transplanted with committed progenitors. Transplantation of autologous adult stem cells without conditioning is a relatively safe therapy. Adult stem cells are known to secrete bioactive factors that suppress the local immune system, inhibit fibrosis (scar formation) and apoptosis, enhance angiogenesis, and stimulate recruitment, retention, mitosis, and differentiation of tissue-residing stem cells. These paracrine effects are distinct from the direct differentiation of stem cells to repair tissue. In patients at high risk while waiting for a liver transplant, autologous stem cell therapy could be considered, as it could delay the decline in liver function.
\end{abstract}

\footnotetext{
P. Zhou $\cdot$ L. Wirthlin · J. McGee $\cdot$ G. Annett $\cdot$ J. Nolta

Department of Internal Medicine, Division of Hematology/

Oncology, Stem Cell Program, University of California,

Sacramento, CA, USA

J. Nolta $(\square)$

Stem Cell Program, Department of Internal Medicine,

University of California, Davis,

2700 Stockton Blvd, Room 2132,

Sacramento, CA 95817, USA

e-mail: jan.nolta@ucdmc.ucdavis.edu
}

Keywords Hematopoietic stem cell $\cdot$ Hepatocytes · Cell fusion · Aldehyde dehydrogenase $\cdot$ Liver damage · Regenerative medicine

$\begin{array}{ll}\text { Abbreviations } \\ \text { AAT } & \alpha \text {-1-antitrypsin } \\ \text { ALB } & \text { albumin } \\ \text { ALDH } & \text { aldehyde dehydrogenase } \\ \text { ALDH }^{\text {hi }} & \text { high activity of ALDH } \\ \text { ALDH }^{\text {lo }} & \text { low activity of ALDH } \\ \text { BMSC }^{\text {bCl }} & \text { bone marrow stem cell } \\ \text { DAPI } & \text { carbon tetrachloride } \\ \text { FACS } & \text { flo-diaminidino-2-phenylindole } \\ \text { FAH } & \text { fumarylacetoacetate hydrolase } \\ \text { FISH } & \text { fluorescent in situ hybridization } \\ \text { GUSB } & \text { beta-glucuronidase } \\ \text { hCBSC } & \text { human cord blood stem cells } \\ \text { HNF1 } & \text { hepatocyte nuclear factor 1 } \\ \text { Lin } & \text { lineage-depleted } \\ \text { MPS VII } & \text { mucopolysaccharidosis type VII } \\ \text { NOD/ } & \text { nonobese diabetic/severe combined immuno- } \\ \text { SCID } & \text { deficient }\end{array}$

Tissue-dependent fusion and stem-cell-induced repair of nonhematopoietic tissues including the liver

"Plasticity" refers to the putative ability of adult stem cells to acquire mature cell phenotypes distinct from their tissue of origin. Reports had initially described that transplanted bone marrow (BM)-derived stem cells could generate cells with unexpected phenotypes, including cardiac and skeletal muscle, brain, endothelial, endocrine, and epithelial line- 
ages, in addition to liver (reviewed in $[1,2]$ ). These phenomena occurred at a low frequency in vivo [3] and required tissue damage for stem cell recruitment and selective survival advantage for propagation [4]. Several reports then failed to reproduce original findings [5-7] but other studies demonstrated that transplanted BM cells engrafted nonhematopoietic tissues and stimulated improved function of the damaged organs in vivo $[4,8-10]$. The biological mechanisms responsible for "stem cell plasticity" are still debated, especially in the liver. Recent studies have shown stem cell fusion with mature tissuespecific cells [11-13]. Fusion of transplanted BM-derived cells with damaged cells has been implicated in the production of skeletal muscle [14], neural [15], cardiac [6], and hepatic cells [12, 13, 16]. Cre-recombinasemediated activation of reporter genes has been used to detect cell fusion events after bone marrow transplantation in vivo. Alvarez-Dolado et al. used this system to demonstrate donor bone-marrow-derived cell fusion with mature recipient hepatocytes, cardiomyocytes, and Purkinje cells [15]. Two other groups have used similar Cre-loxP strategies to show the absence of cell fusion $[17,18]$. Ianus et al. [17] used Y chromosome fluorescent in situ hybridization (FISH), in combination with an insulinpromoter-driven Cre/Lox system, to show the production of BM-derived insulin-producing cells without Cremediated activation of enhanced green fluorescence protein through cell fusion. We have shown that, although relatively rare, cell fusion does exist in vivo between transplanted human stem cells and recipient immunedeficient mouse hepatocytes, resulting in human albuminexpressing cells [19]. However, Harris et al. identified epithelial cells in the lung, skin, and liver that develop from BM-derived cells through a mechanism other than cell fusion [18]. Cell fusion may be a cell-type-specific phenomenon that is more common in organs that normally contain cells with different ploidies such as liver and muscle and can be induced by acute physiologic injury. In addition, it seems probable that alternate mechanisms, such as the induction of angiogenic processes [20] and stem-cellmediated enhancement of cellular proliferation [10], are involved in the cumulative benefit of stem-cell-mediated repair of nonhematopoietic organs.

Liver transplantation remains the only therapeutic option for many acute and chronic end-stage liver diseases. However, this approach is limited by a serious shortage of donor organs required for transplantation. A number of studies have suggested that stem cells from bone marrow could generate hepatocytes (reviewed in [21]). The most successful liver repopulation with bone-marrow-derived cells was observed in mice with fumarylacetoacetate hydrolase $\left(\mathrm{FAH}^{-}-\mathrm{-}\right)$ deficiency resulting in functional correction of the liver disease $[4,12,13]$. In this excellent model, there is a strong selection for corrected donor hepatocytes that express the functional enzyme, in contrast to other liver damage models where the endogenous recipient cells can also contribute to the repair. In the xenotransplantation models with human cells injected into mice, the contribution from the donor human cells to the damaged liver can be easily observed by human-specific markers or centromeric chromosome analysis by FISH that discriminate between murine and human chromosomes (Fig. 1) [22, 23].

\section{Isolation of hematopoietic stem cells for liver repair using phenotypic vs. functional markers}

Methods to identify the most primitive hematopoietic stem cells (HSC) are constantly sought. The CD34 protein is frequently used as a marker for positive selection of human hematopoietic stem and progenitor cells. However, Goodell et al. $[24,25]$ characterized murine Hoechst dye-excluding side population cells that lacked CD34 expression and had reconstitution capacity. Bhatia et al. [26] demonstrated a low level of engraftment activity in human CD34- cells. We showed that highly purified human $\mathrm{CD} 34+$ cells generated CD34- cells in immune-deficient mice after 1 year and that the reisolated human CD34- cells retained the capacity to regenerate $\mathrm{CD} 34+$ cells upon secondary transplantation. We determined that $\mathrm{CD} 34$ expression at the cell surface and messenger RNA (mRNA) level can be turned on and off, relating to the quiescence of the human hematopoietic stem

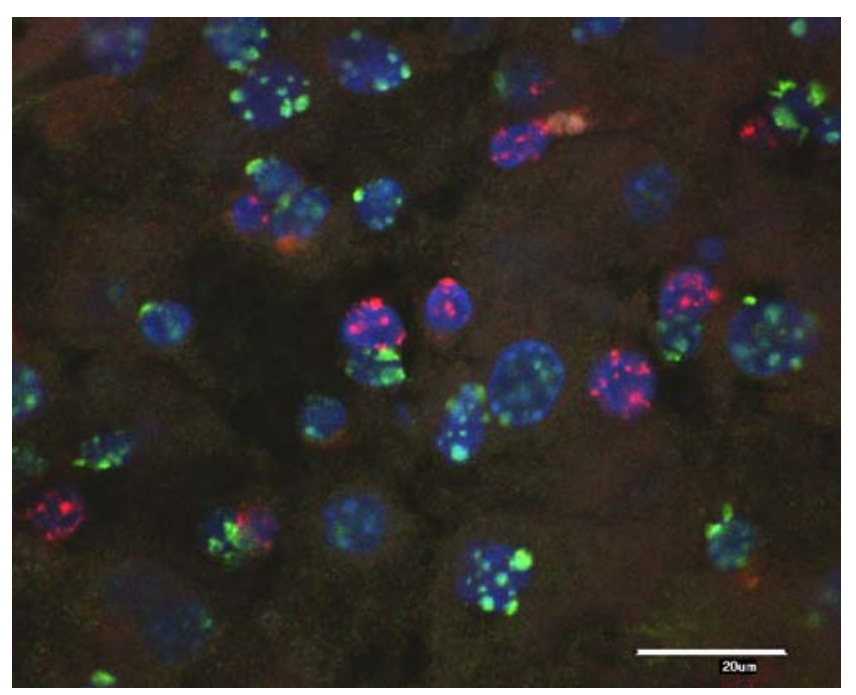

Fig. 1 FISH analysis for human and mouse centromeres in liver sections. Liver sections from a mouse that had been transplanted with $\mathrm{ALDH}^{\mathrm{hi}} \mathrm{Lin}^{-}$cells after CCL4-mediated liver injury were probed with both human (red dots in nuclei) and mouse (green dots in nuclei) centromeric probes. The analysis shows that the liver was heavily engrafted with human stem cells and that the majority of the human cells had not undergone fusion with the damaged murine hepatocytes 
cell population in vivo [27]. Human CD34+/CD38- cells engraft in beige/nude/xid immune-deficient mice and their progeny can be recovered from the murine bone marrow for as long as 18 months posttransplantation [28, 29]. When reisolated from the marrow of beige/nude/xid mice, the human cells were absolutely devoid of CD34 expression. No CD34 mRNA was detected in the human CD45+ cells, reisolated from the bnx bone marrow. The human $\mathrm{CD} 45+/$ CD34- cells generated multilineage reconstitution in secondary nonobese diabetic/severe combined immunodeficient (NOD/SCID) recipients. CD34+ cells were recovered from the secondary recipients, demonstrating that CD34 expression is reversible: CD45+/CD34+/CD38cells can generate $\mathrm{CD} 45+/ \mathrm{CD} 34-$ cells, which can then generate $\mathrm{CD} 45+/ \mathrm{CD} 34+$ cells. Our data agree with reports from Makio Ogawa's group [30], which indicate that CD34 expression may be an activation-dependent event. Hess and Bhatia had independently found that after coculture and transplantation into immune-deficient mice, male CD34-/ Lin- cells generated CD34+/CD38- cells, which, upon recovery from the mice, demonstrated clonogenic progenitor function into multiple lineages [31]. These data demonstrated that expression of CD34 is reversible on human multilineage engrafting stem/progenitor cells [27, 32]. This calls for different purification strategies, based on conserved stem cell function as well as phenotype, to avoid "missing" the most primitive or multipotent cells within the bone marrow.

Since we and others have shown that human hematopoietic cell phenotype can vary with activation state [27, $30,31,33$, we therefore sought a functional rather than phenotypic method for identifying human stem cells with regenerative potential. The use of metabolic markers such as rhodamine and Hoechst 33342 dye efflux separates cells based on high expression of membrane pumps encoded by the multiple drug resistance genes, a characteristic believed to be associated with very immature stem/progenitor cells $[24,25,34,35]$. Another very interesting metabolic marker indicative of early immature cells is the enzyme aldehyde dehydrogenase (ALDH), shown by our group and others to correlate with high stem cell activity in vivo [36-38]. In our studies, progenitor function and reconstituting ability were exclusive to the ALDH high and lineage-depleted fraction $\left(\mathrm{ALDH}^{\mathrm{hi}} \mathrm{Lin}^{-}\right)$, as opposed to the $\mathrm{ALDH}^{\mathrm{lo}} \mathrm{Lin}^{-}$population [38]. We also examined the combination of ALDH activity with markers such as CD133, the human homolog of prominin 5-transmembrane glycoproteins, which is also a prominent HSC marker [38-43]. Fractionation of human HSC based on high ALDH activity, with and without other markers such as CD133, provided a rigorous selection of purified stem and progenitor cells [38, 44]. We have subsequently shown that $\mathrm{ALDH}^{\text {hi }} \mathrm{Lin}^{-}$cells represent a unique mixed stem cell population with hematopoietic, mesenchymal, and endothelial progenitor function [45] and have examined the function of this population in tissue repair, including the liver, as described further below.

\section{Role of hepatocyte growth factor in stem cell survival, recruitment, and tissue repair}

Hepatocyte growth factor (HGF)/scatter factor is a mesenchymal-derived heparin-binding glycoprotein that has effects on the survival, mitosis, and migration of many cell types. HGF induces gradient-directed migration (chemotaxis) and invasion through extracellular matrix proteins. It induces a program of activities in migrating cells that are required for invasion into tissues [46-48]. The mature molecule is an $\alpha \mathrm{B}$ heterodimer that is cleaved from a single polypeptide precursor. When expressed from vectors in mammalian cells, the precursor protein is appropriately cleaved to form the active heterodimer [49, 50]. The receptor for HGF is the transmembrane tyrosine kinase cMet [51]. Both HGF activation and c-Met expression are inducible by hypoxia. In addition to its established role in stimulation of hepatocyte survival, migration, and division, HGF has been found to play a role in hematopoiesis. The HGF protein is produced by marrow stromal cells, which suggests that it may have a role in the maintenance of HSC. c-Met is expressed on hematopoietic progenitors that respond to HGF [52-60] as well as cells that are capable of regenerating liver and muscle, in its better known roles (reviewed in [61]). c-Met is expressed on immature human marrow-derived hematopoietic stem/progenitor cells with the phenotype CD34+CD33- and CD34+CD38- but not on more mature progenitors with the phenotype $\mathrm{CD} 34+\mathrm{CD} 33+$ and $\mathrm{CD} 34+\mathrm{CD} 38+[59]$.

HGF also plays an important role in tissue repair. During regeneration, expression of HGF from the damaged tissue is upregulated and later downregulated in controlled patterns $[62,63]$. The role of HGF in repair has been well documented in the liver. Kupffer cells in the liver upregulate HGF mRNA following liver injury, and expression of HGF by endothelial cells in local capillary beds is also induced [64, 65]. HGF is also upregulated by the mouse heart in response to myocardial ischemia, and, after myocardial infarction in humans, HGF secretion was also upregulated from the infarcted region [66, 67]. HGF also stimulates the activation and early division of adult satellite cells in muscle tissue and is present in injured skeletal muscle [68]. HGF levels are systemically elevated in the serum of patients with liver failure, supporting the idea that the liver may be attempting to recruit stem cells to assist with its repair and regeneration. To gain a better understanding of the role of stem cells in liver and muscle repair, we have examined how these cells might be recruited to 
damaged tissues. One of the primary signals that the stem cells receive after tissue injury may be the hypoxia-induced local activation of HGF, which could act in a gradientdependent manner, to induce stem cell migration into the damaged tissue and to contribute to repair and survival of stem/progenitor cells at the site of damage.

\section{Effects of hypoxia at sites of tissue damage on stem cell phenotype and migration}

Recent characterization of the BM microenvironment has shown that the most primitive hematopoietic stem cells are distributed along an oxygen gradient. Primitive stem cells reside in the most hypoxic areas of the $\mathrm{BM}$ where low $\mathrm{O}_{2}$ levels enhance the survival and expansion of primitive selfrenewing $\mathrm{HSC}$ and endothelial progenitors [69, 70]. Differentiating progenitors reside predominantly in the more vascular sinuses. Progenitor cell trafficking is controlled by chemokine-mediated interactions to regulate the development and release of mature cells into the periphery [71]. CXCR4 and c-Met have both been reported to be expressed on bone marrow-derived HSC and we demonstrated that they can both be increased in hypoxic cultures [72]. CXCR4 has recently been reported to be present as a cytosolic protein pool in addition to its surface expression, raising the intriguing question of whether changes in the microenvironment, such as hypoxia or HGF administration, could enhance the delivery of the cytosolic protein to the extracellular surface. c-Met, the receptor for HGF, is rapidly internalized and degraded following ligand binding. There is evidence from our laboratory and others to show that hypoxia enhances not only the expression of c-Met but also its protein stability and signaling to downstream prosurvival factors [72, 73].
Following chemical-induced liver injury, such as in the CCL4 model that we have reported, damage to the proximal capillaries is a major outcome. The immediate microenvironment surrounding these capillaries will thus be hypoxic. This local hypoxia may induce an upregulation in the active levels of local chemoattractants and growth factors such as HGF and stromal-derived factor 1 in the damaged region of tissue. This combination of low oxygen tension and high chemoattractant gradient may promote the recruitment of tissue- repairing stem cells to the damaged liver site. The fact that marrow-derived stem cells can be found at sites of liver injury (Fig. 2) suggests that they can be recruited to the hypoxic region and that they can survive in the damaged microenvironment. This suggests that stem cells might adapt a phenotype that allows survival in a hypoxic environment, perhaps induced by HGF, a known survival factor for multiple stem cell types.

To explore this theory, we set up an immune-deficient mouse model of liver damage and recovery and determined that CCL4 allowed better human cell engraftment and induction of human albumin expression than radiation or allyl alcohol damage. We transplanted CD34+ or CD34+/ CD38-/CD7- purified hematopoietic stem cells from human BM and umbilical cord blood (UCB). CD34+/ CD38- cells have been previously defined to be highly quiescent [74-77], and CD34+/CD38-/CD7- cells are a subset of this progenitor pool, shown to generate both lymphoid and myeloerythroid progeny [78]. There was no albumin expression in this population prior to transplantation into the mice [79]. Two months after transplantation into noninjured mice, human hematopoietic cells were present in the murine livers, but none expressed human albumin. However, when $\mathrm{CCl}_{4}$ was administered 1 month after human stem cell transplantation, the human stem cells were induced to begin expressing human albumin [79]. We

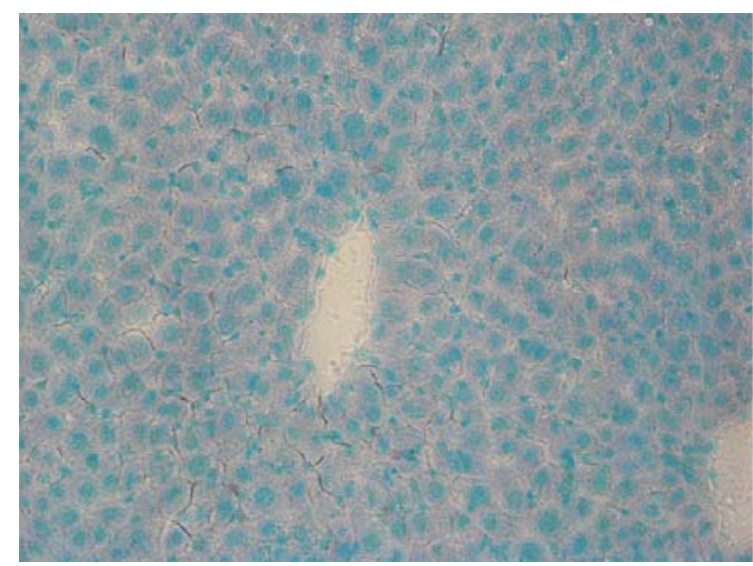

Fig. 2 MPSVII liver. Engraftment of human $\mathrm{ALDH}^{\mathrm{hi}} \mathrm{Lin}^{-}$cells into mouse livers. Representative frozen section slides from the livers of mice transplanted with human cord blood $\mathrm{ALDH}^{\mathrm{lo}} \mathrm{Lin}^{-}$(left) or

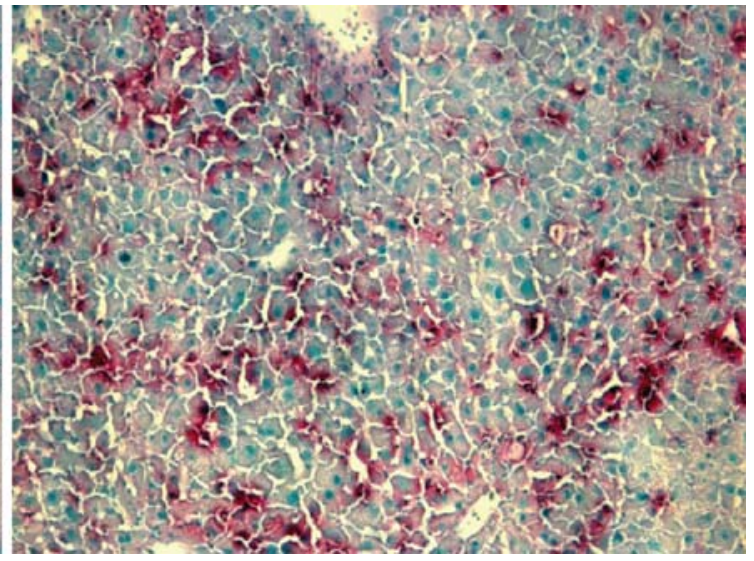

$\mathrm{ALDH}^{\mathrm{hi}} \mathrm{Lin}^{-}$cells (right). Liver sections were stained for $\beta$ glucuronidase (red) and counterstained for methyl green (green nuclei) 
next tested injection of human HGF into the mice vs. transplantation of HGF-expressing mesenchymal stem cells/marrow stromal cells (MSC), using techniques that we had previously described to produce sustained systemic levels of specific growth factors from the engineered cells [80-82]. HGF production from the engineered MSC accelerated and increased the development of human albumin-expressing cells, which could be detected as early as 5 days after the liver injury in some cases [79]. We did not know at that point whether the hepatocyte-like human albumin-producing cells arose via differentiation or fusion, and determining this was a goal of our subsequent studies.

\section{Tissue localization of transplanted human stem cells in immune-deficient mice}

We have studied the in vivo localization of transplanted $\mathrm{ALDH}^{\text {hi }} \mathrm{Lin}^{-}$cells, as well as adipose and marrow-derived MSC subpopulations, into specific tissues of immunedeficient mice, during steady state vs. chronic and acute injury in tissues including liver. In these studies, we are specifically seeking populations of human cells that cannot only home into the injured murine tissues but those that could also mediate repair in a robust manner. These studies were greatly facilitated by the use of a new mouse model, the NOD/SCID/mucopolysaccharidosis type VII (MPSVII) strain developed by Dr. M. Sands [83]. MPSVII is a lysosomal storage disease caused by a deficiency in Bglucuronidase (GUSB) activity. The MPSVII mutation was backcrossed onto the NOD/SCID strain, and human CD34+ cells engraft in the resultant NOD/SCID/MPSVII strain to levels equivalent to the NOD/SCID parent [83]. Tissue slides prepared from this strain allow rapid visualization of human cells which carry normal levels of GUSB, against the background mouse tissues which are null for the enzyme (Fig. 2). Following the enzymatic reaction, slides can be counterstained with antibodies to a tissue-specific protein marker. The enzymatic stain is quite specific, and, although the released enzyme can be taken up by neighboring cells, it is in a processed form no longer detectable by the histochemical analysis. Thus, the individual transplanted human cells stand out vividly against the background GUSB-null murine tissues (Fig. 2). Most notably, human cells expressing GUSB can be detected without reliance on the expression of cell surface markers. This is important in tissue repair studies in hypoxic environments, where the phenotype of homed stem cells can be dramatically different from that of the transplanted population. The use of the GUSB enzyme staining to detect human cells in NOD/SCID MPSVII mice is proving to be more fast and efficient than FISH, although we and others do still use $\mathrm{Y}$ chromosome and centromeric FISH for verification of antibody and enzymatic staining methods (Fig. 1).

Because donor cell surface protein expression can be altered in nonhematopoietic tissues due to cell fusion or other mechanisms, we used the NOD/SCID/MPSVII model to study the tissue distribution of $\mathrm{ALDH}^{\mathrm{hi}} \mathrm{Lin}^{-}$vs. ALDH${ }^{10} \mathrm{Lin}^{-}$cells in liver repair. Injection of the $\mathrm{ALDH}^{\mathrm{lo}} \mathrm{Lin}^{-}$ population, which contains committed progenitors but not stem cells, did not produce significant human cell engraftment in any tissue. In contrast, injection of $2-4 \times 10^{5}$ $\mathrm{ALDH}^{\text {hi }} \mathrm{Lin}^{-}$cells into sublethally irradiated (300 cGy) NOD/SCID/MPSVII mice demonstrated high levels of hematopoietic cell engraftment in the BM $(70.5 \pm 15.1 \%)$, spleen $(7.0 \pm 2.8 \%)$, and peripheral blood $(17.0 \pm 10.7 \%)$. Significant human engraftment was also detected, with single cell sensitivity, in nonhematopoietic tissues (liver, pancreas, kidney, lung, heart, skeletal muscle, and brain) of mice transplanted with the ALDH ${ }^{\text {hi }}$ Lin $^{-}$cells. An example of the specificity of locating transplanted human cells in murine tissue sections is shown in Fig. 2. GUSB activity was colocalized with CD45 expression in the BM of mice transplanted with $\mathrm{ALDH}^{\mathrm{hi}} \mathrm{Lin}^{-}$cells. Histochemical staining confirmed the presence of GUSB + cells that did not express human CD45 and had hepatocyte morphology [84]. These hepatocyte-like GUSB+ cells were also present after the transplantation of the more purified $\mathrm{ALDH}^{\mathrm{hi}} \mathrm{CD} 133$ $+\mathrm{Lin}^{-}$subpopulation, which is greatly enriched for human stem cells [44]. In the pancreas, GUSB + donor cells were localized in ductal regions and surrounding recipient islets. The ALDH ${ }^{\text {hi }}$ Lin $^{-}$UCB cells demonstrated a previously uncharacterized high level of engraftment in nonhematopoietic organs of NOD/SCID MPSVII mice [84]. We next investigated cellular fusion and nuclear reprogramming as a putative mechanism for the production of nonhematopoietic murine cells expressing donor human cell-derived GUSB and albumin.

Gene transfer from donor to recipient cell can potentially occur through fusion, as elegantly demonstrated by other groups in liver [12, 13, 16, 22] and muscle [85]. We wondered whether cell fusion was playing a major role in the tissue repair that we were observing to be mediated by the different human stem cell populations. We used FISH to assess human cells in the damaged livers of immunedeficient mice, using probes for human ALU repeats [79]. This technique proved to be sensitive enough to detect human albumin-expressing hepatocyte-like cells in the heavily damaged mouse livers, and all human albuminexpressing binucleate cells had human DNA expression in both nuclei [79]. However, this technique did not rule out the possible presence of murine DNA in the same cells, which would be a demonstration of fusion.

To examine the issue of fusion in a more detailed manner, we performed a further series of studies that 
examined the contribution of human umbilical-cord-bloodderived stem cells (hCBSC) to liver repair. The frequency of hCBSC-derived hepatocytes varies tremendously between different studies and it is still controversial as to whether hCBSC-derived cells can transdifferentiate into hepatocytes or simply fuse to recipient hepatocytes. We used the GUSB-deficient NOD/SCID/MPSVII mouse model for better identification of engrafted cells. We transplanted lineage-depleted human umbilical-cordblood-derived cells that had been isolated on the basis of high aldehyde dehydrogenase activity $\left(\mathrm{ALDH}^{\mathrm{hi}} \mathrm{Lin}^{-}\right)$ into irradiated NOD/SCID/MPSVII mice followed by carbon tetrachloride administration to induce liver damage. We found that the ALDH ${ }^{\text {hi }}$ Lin $^{-}$cells engrafted efficiently into the recipient mouse livers and that they improved recovery of the mice from toxic insult. The percentage of human cells in these livers ranged between 3\% and 14.2\% using quantitative real-time polymerase chain reaction. Human cells expressing liver-specific $\alpha-1$-antitrypsin mRNA, albumin, and hepatocyte nuclear factor 1 protein were detected in the recipient livers [86]. Interestingly, human vs. murine centromeric fluorescent in situ hybridization analysis on the liver sections demonstrated that most human cells were not fused to murine cells (Fig. 1). However, the majority of the rarer human-originated albumin-expressing cells did also carry mouse genetic material and therefore were the product of cell fusion.

We have previously shown that highly purified CD34 +CD38-CD7- human cord blood stem cells with known potent hematopoietic potential could give rise to hepatocyte-like cells in immunodeficient mice [79]. However, the frequency of hepatocyte-like cells derived from hematopoietic cells in mouse models is rare [21]. The mechanisms responsible for these phenomena are also still somewhat controversial. Both direct transdifferentiation $[18,87,88]$ of bone marrow and umbilical-cord-bloodderived stem cells to hepatocytes and fusion between BMSC-derived cells and recipient hepatocytes have been reported [12, 13, 15, 22, 89-91]. In our most recent studies, limited numbers $(0.05 \%)$ of hepatocyte-like cells derived from CBSCs were detected in the recipient livers while significant numbers of donor cells, mostly hematopoietic, were engrafted to the liver following damage. Similar low frequencies of bone-marrow-derived hepatocytes were reported by others [21] and thus represent an obstacle to clinical application.

However, CBSC-derived cells may contribute indirectly to liver regeneration. Hematopoietic cells are capable of producing cytokines, such as interleukin 6 , tumor necrosis factor alpha, HGF, and others, to stimulate hepatocyte proliferation [92, 93]. It has also been reported that BMSCs can partially repair $\mathrm{CCl}_{4}$-induced fibrosis of the mouse liver through the activation of metalloproteinase- 9
[94]. In agreement with those data, we observed significantly higher levels of survival in the mice that had been transplanted with human $\mathrm{ALDH}^{\mathrm{hi}} \mathrm{Lin}^{-}$stem cells in comparison to nontransplanted controls and those transplanted with $\mathrm{ALDH}^{\mathrm{lo}} \mathrm{Lin}^{-}$cells, which represent committed progenitors. We conclude that human stem cells or their progeny may home to the injured liver and release paracrine factors that hasten tissue repair, while fusion of these cells with hepatocytes occurs rarely and contributes to a lesser extent to liver repair [86].

In summary, our data show that human bone-marrowand cord-blood-derived stem cells or their progeny can fuse with host hepatocytes and that the fused cells gradually lose human genetic material. Our most recent data demonstrate that human albumin-expressing cells were generated from fusion of human cord-blood-derived cells with the recipient murine hepatocytes. The CD34+ and ALDH high stem cell subsets from both marrow and umbilical cord blood did however have a significant potential to repair liver through paracrine effects, and the human ALDH high stem cells caused a significant increase in survival of immunedeficient mice that had been given a toxic liver insult. Our data suggest that the primary beneficial effects from adult stem cell transplantation to injured liver may not be from direct generation of new hepatocytes but rather through the reparative paracrine effects that the engrafted stem cells exert on the damaged tissue.

Financial support NIDDK R01DK61848 (JN), NHLBI R01HL073256 (JN), and Stem Cell Program Start-up funding from the Office of the Dean of the UC Davis School of Medicine

Open Access This article is distributed under the terms of the Creative Commons Attribution Noncommercial License which permits any noncommercial use, distribution, and reproduction in any medium, provided the original author(s) and source are credited.

\section{References}

1. Wagers AJ, Weissman IL (2004) Plasticity of adult stem cells. Cell 116:639-648

2. Grove JE, Bruscia E, Krause DS (2004) Plasticity of bone marrow-derived stem cells. Stem Cells 22:487-500

3. Wagers AJ, Sherwood RI, Christensen JL, Weissman IL (2002) Little evidence for developmental plasticity of adult hematopoietic stem cells. Science 297:2256-2259

4. Lagasse E, Connors H, Al-Dhalimy M, Reitsma M, Dohse M, Osborne L, Wang X, Finegold M, Weissman IL, Grompe M (2000) Purified hematopoietic stem cells can differentiate into hepatocytes in vivo. Nat Med 6:1229-1234

5. Balsam LB, Wagers AJ, Christensen JL, Kofidis T, Weissman IL, Robbins RC (2004) Haematopoietic stem cells adopt mature haematopoietic fates in ischaemic myocardium. Nature 428:668-673 
6. Nygren JM, Jovinge S, Breitbach M, Sawen P, Roll W, Hescheler J, Taneera J, Fleischmann BK, Jacobsen SE (2004) Bone marrowderived hematopoietic cells generate cardiomyocytes at a low frequency through cell fusion, but not transdifferentiation. Nat Med 10:494-501

7. Murry CE, Soonpaa MH, Reinecke H, Nakajima H, Nakajima HO, Rubart M, Pasumarthi KB, Virag JI, Bartelmez SH, Poppa V, Bradford G, Dowell JD, Williams DA, Field LJ (2004) Haematopoietic stem cells do not transdifferentiate into cardiac myocytes in myocardial infarcts. Nature 428:664-668

8. Orlic D, Kajstura J, Chimenti S, Jakoniuk I, Anderson SM, Li B, Pickel J, McKay R, Nadal-Ginard B, Bodine DM, Leri A, Anversa P (2001) Bone marrow cells regenerate infarcted myocardium. Nature 410:701-705

9. Park KI, Teng YD, Snyder EY (2002) The injured brain interacts reciprocally with neural stem cells supported by scaffolds to reconstitute lost tissue. Nat Biotechnol 20:1111-1117

10. Hess D, Li L, Martin M, Sakano S, Hill D, Strutt B, Thyssen S, Gray DA, Bhatia M (2003) Bone marrow-derived stem cells initiate pancreatic regeneration. Nat Biotechnol 21:763-770

11. Terada N, Hamazaki T, Oka M, Hoki M, Mastalerz DM, Nakano Y, Meyer EM, Morel L, Petersen BE, Scott EW (2002) Bone marrow cells adopt the phenotype of other cells by spontaneous cell fusion. Nature 416:542-545

12. Vassilopoulos G, Wang PR, Russell DW (2003) Transplanted bone marrow regenerates liver by cell fusion. Nature 422:901-904

13. Wang X, Willenbring H, Akkari Y, Torimaru Y, Foster M, AlDhalimy M, Lagasse E, Finegold M, Olson S, Grompe M (2003) Cell fusion is the principal source of bone-marrow-derived hepatocytes. Nature 422:897-901

14. Corbel SY, Lee A, Yi L, Duenas J, Brazelton TR, Blau HM, Rossi FM (2003) Contribution of hematopoietic stem cells to skeletal muscle. Nat Med 9:1528-1532

15. Alvarez-Dolado M, Pardal R, Garcia-Verdugo JM, Fike JR, Lee HO, Pfeffer K, Lois C, Morrison SJ, Alvarez-Buylla A (2003) Fusion of bone-marrow-derived cells with Purkinje neurons, cardiomyocytes and hepatocytes. Nature 425:968-973

16. Willenbring H, Bailey AS, Foster M, Akkari Y, Dorrell C, Olson S, Finegold M, Fleming WH, Grompe M (2004) Myelomonocytic cells are sufficient for therapeutic cell fusion in liver. Nat Med 10:744-748

17. Ianus A, Holz GG, Theise ND, Hussain MA (2003) In vivo derivation of glucose-competent pancreatic endocrine cells from bone marrow without evidence of cell fusion. J Clin Invest 111:843-850

18. Harris RG, Herzog EL, Bruscia EM, Grove JE, Van Arnam JS, Krause DS (2004) Lack of a fusion requirement for development of bone marrow-derived epithelia. Science 305:90-93

19. Zhou P, Hohm S, Olusanya Y, Hess DA, Nolta J (2009) Human progenitor cells with high aldehyde dehydrogenase activity efficiently engraft into damaged liver in a novel model. Hepatology 49:1992-2000

20. Botta R, Gao E, Stassi G, Bonci D, Pelosi E, Zwas D, Patti M, Colonna L, Baiocchi M, Coppola S, Ma X, Condorelli G, Peschle C (2004) Heart infarct in NOD-SCID mice: therapeutic vasculogenesis by transplantation of human $\mathrm{CD} 34+$ cells and low dose CD34+KDR+ cells. Faseb J 1:1

21. Thorgeirsson SS, Grisham JW (2006) Hematopoietic cells as hepatocyte stem cells: a critical review of the evidence. Hepatology 43:2-8

22. Kashofer K, Siapati EK, Bonnet D (2006) In vivo formation of unstable heterokaryons after liver damage and hematopoietic stem cell/progenitor transplantation. Stem Cells 24:1104-1112

23. Zhou P, Hohm S, Capoccia B, Wirthlin L, Hess D, Link D, Nolta J (2008) Immunodeficient mouse models to study human stem cellmediated tissue repair. Methods Mol Biol 430:213-225
24. Goodell MA, Brose K, Paradis G, Conner AS, Mulligan RC (1996) Isolation and functional properties of murine hematopoietic stem cells that are replicating in vivo. J Exp Med 183:17971806

25. Goodell MA, Rosenzweig M, Kim H, Marks DF, DeMaria M, Paradis G, Grupp SA, Sieff CA, Mulligan RC, Johnson RP (1997) Dye efflux studies suggest that hematopoietic stem cells expressing low or undetectable levels of CD34 antigen exist in multiple species. Nat Med 3:1337-1345

26. Bhatia M, Bonnet D, Murdoch B, Gan OI, Dick JE (1998) A newly discovered class of human hematopoietic cells with SCIDrepopulating activity [see comments]. Nat Med 4:1038-1045

27. Dao MA, Arevalo J, Nolta JA (2003) Reversibility of CD34 expression on human hematopoietic stem cells that retain the capacity for secondary reconstitution. Blood 101:112-118

28. Dao MA, Shah AJ, Crooks GM, Nolta JA (1998) Engraftment and retroviral marking of $\mathrm{CD} 34+$ and $\mathrm{CD} 34+\mathrm{CD} 38$ - human hematopoietic progenitors assessed in immune-deficient mice. Blood 91:1243-1255

29. Dao MA, Taylor N, Nolta JA (1998) Reduction in levels of the cyclin-dependent kinase inhibitor p27(kip-1) coupled with transforming growth factor beta neutralization induces cell-cycle entry and increases retroviral transduction of primitive human hematopoietic cells. Proc Natl Acad Sci U S A 95:13006-13011

30. Sato T, Laver JH, Ogawa M (1999) Reversible expression of CD34 by murine hematopoietic stem cells [see comments]. Blood 94:2548-2554

31. Hess DA, Karanu FN, Levac K, Gallacher L, Bhatia M (2003) Coculture and transplant of purified CD34(+) Lin(-) and CD34(-) Lin(-) cells reveals functional interaction between repopulating hematopoietic stem cells. Leukemia 17:1613-1625

32. Dao MA, Nolta JA (2000) CD34: to select or not to select? That is the question. Leukemia 14:773-776

33. Zanjani ED, Almeida-Porada G, Livingston AG, Porada CD, Ogawa M (1999) Engraftment and multilineage expression of human bone marrow CD34- cells in vivo. Ann N Y Acad Sci 872:220-231 discussion 231-222

34. Storms RW, Goodell MA, Fisher A, Mulligan RC, Smith C (2000) Hoechst dye efflux reveals a novel CD7(+) CD34(-) lymphoid progenitor in human umbilical cord blood. Blood 96:2125-2133

35. Cai J, Weiss ML, Rao MS (2004) In search of "stemness". Exp Hematol 32:585-598

36. Fallon P, Gentry T, Balber AE, Boulware D, Janssen WE, Smilee R, Storms RW, Smith C (2003) Mobilized peripheral blood SSCloALDHbr cells have the phenotypic and functional properties of primitive haematopoietic cells and their number correlates with engraftment following autologous transplantation. $\mathrm{Br} \mathrm{J}$ Haematol 122:99-108

37. Storms RW, Trujillo AP, Springer JB, Shah L, Colvin OM, Ludeman SM, Smith C (1999) Isolation of primitive human hematopoietic progenitors on the basis of aldehyde dehydrogenase activity. Proc Natl Acad Sci U S A 96:9118-9123

38. Hess DA, Meyerrose TE, Wirthlin L, Craft TP, Herrbrich PE, Creer MH, Nolta JA (2004) Functional characterization of highly purified human hematopoietic repopulating cells isolated based on aldehyde dehydrogenase activity. Blood 104:16481655

39. Lang P, Bader P, Schumm M, Feuchtinger T, Einsele H, Fuhrer M, Weinstock C, Handgretinger R, Kuci S, Martin D, Niethammer D, Greil J (2004) Transplantation of a combination of CD133+ and $\mathrm{CD} 34+$ selected progenitor cells from alternative donors. Br J Haematol 124:72-79

40. Forraz N, Pettengell R, McGuckin CP (2004) Characterization of a lineage-negative stem-progenitor cell population optimized for ex vivo expansion and enriched for LTC-IC. Stem Cells 22:100-108 
41. Wagner W, Ansorge A, Wirkner U, Eckstein V, Schwager C, Blake J, Miesala K, Selig J, Saffrich R, Ansorge W, Ho AD (2004) Molecular evidence for stem cell function of the slowdividing fraction among human hematopoietic progenitor cells by genome-wide analysis. Blood 104:675-686

42. Ruzicka K, Grskovic B, Pavlovic V, Qujeq D, Karimi A, Mueller MM (2004) Differentiation of human umbilical cord blood CD133 + stem cells towards myelomonocytic lineage. Clin Chim Acta 343:85-92

43. Bhatia M (2001) AC133 expression in human stem cells. Leukemia 15:1685-1688

44. Hess DA, Wirthlin L, Craft TP, Herrbrich PE, Hohm SA, Lahey R, Eades WC, Creer MH, Nolta JA (2006) Selection based on CD133 and high aldehyde dehydrogenase activity isolates longterm reconstituting human hematopoietic stem cells. Blood 107:2162-2169

45. Capoccia BJ, Robson DL, Levac KD, Maxwell DJ, Hohm SA, Neelamkavil MJ, Bell GI, Xenocostas A, Link DC, PiwnicaWorms D, Nolta JA, Hess DA (2009) Revascularization of ischemic limbs after transplantation of human bone marrow cells with high aldehyde dehydrogenase activity. Blood 113:5340-5351

46. Bhargava M, Joseph A, Knesel J, Halaban R, Li Y, Pang S, Goldberg I, Setter E, Donovan MA, Zarnegar R et al (1992) Scatter factor and hepatocyte growth factor: activities, properties, and mechanism. Cell Growth Differ 3:11-20

47. Weidner KM, Behrens J, Vandekerckhove J, Birchmeier W (1990) Scatter factor: molecular characteristics and effect on the invasiveness of epithelial cells. J Cell Biol 111:2097-2108

48. Rosen EM, Goldberg ID, Liu D, Setter E, Donovan MA, Bhargava M, Reiss M, Kacinski BM (1991) Tumor necrosis factor stimulates epithelial tumor cell motility. Cancer Res 51:5315-5321

49. Gao C, Jokerst R, Gondipalli P, Cai SR, Kennedy S, Ponder KP (1999) Intramuscular injection of an adenoviral vector expressing hepatocyte growth factor facilitates hepatic transduction with a retroviral vector in mice. Hum Gene Ther 10:911-922

50. Lee HS, Huang GT, Sheu JC, Chiou LL, Lai MY, Chen DS, Lee SC (1993) Characterization of hepatocyte growth factor expressed by baculovirus. Biochem Biophys Res Commun 197:591-598

51. Bottaro DP, Rubin JS, Faletto DL, Chan AM, Kmiecik TE, Vande Woude GF, Aaronson SA (1991) Identification of the hepatocyte growth factor receptor as the c-Met proto-oncogene product. Science 251:802-804

52. Mizuno K, Higuchi O, Ihle JN, Nakamura T (1993) Hepatocyte growth factor stimulates growth of hematopoietic progenitor cells. Biochem Biophys Res Commun 194:178-186

53. Galimi F, Bagnara GP, Bonsi L, Cottone E, Follenzi A, Simeone A, Comoglio PM (1994) Hepatocyte growth factor induces proliferation and differentiation of multipotent and erythroid hematopoietic progenitors. J Cell Biol 127:1743-1754

54. Nishino T, Hisha H, Nishino N, Adachi M, Ikehara S (1995) Hepatocyte growth factor as a hematopoietic regulator. Blood 85:3093-3100

55. Ikehara S (1996) Role of hepatocyte growth factor in hemopoiesis. Leuk Lymphoma 23:297-303

56. Ratajczak MZ, Marlicz W, Ratajczak J, Wasik M, Machalinski B, Carter A, Gewirtz AM (1997) Effect of hepatocyte growth factor on early human haemopoietic cell development. Br J Haematol 99:228-236

57. Yu CZ, Hisha H, Li Y, Lian Z, Nishino T, Toki J, Adachi Y, Inaba M, Fan TX, Jin T, Iguchi T, Sogo S, Hosaka N, Song TH, Xing J, Ikehara S (1998) Stimulatory effects of hepatocyte growth factor on hemopoiesis of SCF/c-kit system-deficient mice. Stem Cells 16:66-77

58. Iguchi T, Sogo S, Hisha H, Taketani S, Adachi Y, Miyazaki R, Ogata H, Masuda S, Sasaki R, Ito M, Fukuhara S, Ikehara
S (1999) HGF activates signal transduction from EPO receptor on human cord blood CD34+/CD45+ cells. Stem Cells 17:82-91

59. Weimar IS, Miranda N, Muller EJ, Hekman A, Kerst JM, de Gast GC, Gerritsen WR (1998) Hepatocyte growth factor/scatter factor (HGF/SF) is produced by human bone marrow stromal cells and promotes proliferation, adhesion and survival of human hematopoietic progenitor cells (CD34+). Exp Hematol 26:885-894

60. Goff JP, Shields DS, Petersen BE, Zajac VF, Michalopoulos GK, Greenberger JS (1996) Synergistic effects of hepatocyte growth factor on human cord blood CD34+ progenitor cells are the result of c-Met receptor expression. Stem Cells 14:592-602

61. Rosen IDGaEM (1995) Epithelial-mesenchymal interactions in cancer. Birkhauser, Basel

62. Nakamura T, Nishizawa T, Hagiya M, Seki T, Shimonishi M, Sugimura A, Tashiro K, Shimizu S (1989) Molecular cloning and expression of human hepatocyte growth factor. Nature 342:440 443

63. Sonnenberg E, Meyer D, Weidner KM, Birchmeier C (1993) Scatter factor/hepatocyte growth factor and its receptor, the c-met tyrosine kinase, can mediate a signal exchange between mesenchyme and epithelia during mouse development. J Cell Biol 123:223-235

64. Noji S, Tashiro K, Koyama E, Nohno T, Ohyama K, Taniguchi S, Nakamura T (1990) Expression of hepatocyte growth factor gene in endothelial and Kupffer cells of damaged rat livers, as revealed by in situ hybridization. Biochem Biophys Res Commun 173:4247

65. Fujimoto J (2000) Gene therapy for liver cirrhosis. J Gastroenterol Hepatol 15:D33-D36

66. Yasuda S, Goto Y, Baba T, Satoh T, Sumida H, Miyazaki S, Nonogi H (2000) Enhanced secretion of cardiac hepatocyte growth factor from an infarct region is associated with less severe ventricular enlargement and improved cardiac function. J Am Coll Cardiol 36:115-121

67. Sato T, Fujieda H, Murao S, Sato H, Takeuchi T, Ohtsuki Y (1999) Sequential changes of hepatocyte growth factor in the serum and enhanced c-Met expression in the myocardium in acute myocardial infarction. Jpn Circ J 63:906-908

68. Sheehan SM, Tatsumi R, Temm-Grove CJ, Allen RE (2000) HGF is an autocrine growth factor for skeletal muscle satellite cells in vitro. Muscle Nerve 23:239-245

69. Danet GH, Pan Y, Luongo JL, Bonnet DA, Simon MC (2003) Expansion of human SCID-repopulating cells under hypoxic conditions. J Clin Invest 112:126-135

70. Ceradini DJ, Kulkarni AR, Callaghan MJ, Tepper OM, Bastidas N, Kleinman ME, Capla JM, Galiano RD, Levine JP, Gurtner GC (2004) Progenitor cell trafficking is regulated by hypoxic gradients through HIF-1 induction of SDF-1. Nat Med 10:858-864

71. Avecilla ST, Hattori K, Heissig B, Tejada R, Liao F, Shido K, Jin DK, Dias S, Zhang F, Hartman TE, Hackett NR, Crystal RG, Witte L, Hicklin DJ, Bohlen P, Eaton D, Lyden D, de Sauvage F, Rafii S (2004) Chemokine-mediated interaction of hematopoietic progenitors with the bone marrow vascular niche is required for thrombopoiesis. Nat Med 10:64-71

72. Rosova I, Dao M, Capoccia B, Link D, Nolta JA (2008) Hypoxic preconditioning results in increased motility and improved therapeutic potential of human mesenchymal stem cells. Stem Cells 26:2173-2182

73. Pennacchietti S, Michieli P, Galluzzo M, Mazzone M, Giordano S, Comoglio PM (2003) Hypoxia promotes invasive growth by transcriptional activation of the met protooncogene. Cancer Cell 3:347-361

74. Hao QL, Shah AJ, Thiemann FT, Smogorzewska EM, Crooks GM (1995) A functional comparison of CD34+ CD38- cells in cord blood and bone marrow. Blood 86:3745-3753 
75. Hao QL, Thiemann FT, Petersen D, Smogorzewska EM, Crooks GM (1996) Extended long-term culture reveals a highly quiescent and primitive human hematopoietic progenitor population. Blood 88:3306-3313

76. Hao QL, Smogorzewska EM, Barsky LW, Crooks GM (1998) In vitro identification of single CD34+ CD38- cells with both lymphoid and myeloid potential. Blood 91:4145-4151

77. Shah AJ, Smogorzewska EM, Hannum C, Crooks GM (1996) Flt3 ligand induces proliferation of quiescent human bone marrow CD34+ CD38- cells and maintains progenitor cells in vitro. Blood 87:3563-3570

78. Hao QL, Zhu J, Price MA, Payne KJ, Barsky LW, Crooks GM (2001) Identification of a novel, human multilymphoid progenitor in cord blood. Blood 97:3683-3690

79. Wang X, Ge S, McNamara G, Hao QL, Crooks GM, Nolta JA (2003) Albumin expressing hepatocyte-like cells develop in the livers of immune-deficient mice transmitted with highly purified human hematopoietic stem cells. Blood 101 (10):4201-4208

80. Dao MA, Pepper KA, Nolta JA (1997) Long-term cytokine production from engineered primary human stromal cells influences human hematopoiesis in an in vivo xenograft model. Stem Cells 15:443-454

81. Nolta JA, Hanley MB, Kohn DB (1994) Sustained human hematopoiesis in immunodeficient mice by cotransplantation of marrow stroma expressing human interleukin-3: analysis of gene transduction of long-lived progenitors. Blood 83:3041-3051

82. Tsark E, Dao M, Wang X, Weinberg K, Nolta J (2001) IL-7 enhances the responsiveness of human $T$ cells that develop in the bone marrow of athymic mice. J Immunol 166:170-181

83. Hofling AA, Vogler C, Creer MH, Sands MS (2003) Engraftment of human CD34+ cells leads to widespread distribution of donorderived cells and correction of tissue pathology in a novel murine xenotransplantation model of lysosomal storage disease. Blood 101:2054-2063

84. Hess DA, Craft TP, Wirthlin L, Hohm S, Zhou P, Eades WC, Creer MH, Sands MS, Nolta JA (2008) Widespread nonhematopoietic tissue distribution by transplanted human progenitor cells with high aldehyde dehydrogenase activity. Stem Cells 26:611620

85. Camargo FD, Green R, Capetenaki Y, Jackson KA, Goodell MA (2003) Single hematopoietic stem cells generate skeletal muscle through myeloid intermediates. Nat Med 9:1520-1527

86. Zhou PRL, Hohm S, Tran H, Hess D, Nolta J (2009) Liver engraftment by transplanted human cord blood progenitors and human embryonic stem cells in a novel model, the NOD/SCID/ MPSVII mouse. Hepatology (in press)

87. Jang YY, Collector MI, Baylin SB, Diehl AM, Sharkis SJ (2004) Hematopoietic stem cells convert into liver cells within days without fusion. Nat Cell Biol 6:532-539

88. Muraca M, Ferraresso C, Vilei MT, Granato A, Quarta M, Cozzi E, Rugge M, Pauwelyn KA, Caruso M, Avital I, Inderbitzin D, Demetriou AA, Forbes SJ, Realdi G (2007) Liver repopulation with bone marrow derived cells improves the metabolic disorder in the Gunn rat. Gut 56:1725-1735

89. Camargo FD, Finegold M, Goodell MA (2004) Hematopoietic myelomonocytic cells are the major source of hepatocyte fusion partners. J Clin Invest 113:1266-1270

90. Sharma AD, Cantz T, Richter R, Eckert K, Henschler R, Wilkens L, Jochheim-Richter A, Arseniev L, Ott M (2005) Human cord blood stem cells generate human cytokeratin 18-negative hepatocyte-like cells in injured mouse liver. Am J Pathol 167:555-564

91. Fujino H, Hiramatsu H, Tsuchiya A, Niwa A, Noma H, Shiota M, Umeda K, Yoshimoto M, Ito M, Heike T, Nakahata T (2007) Human cord blood CD34+ cells develop into hepatocytes in the livers of NOD/SCID/gamma(c) null mice through cell fusion. Faseb J 21:3499-3510

92. Selzner N, Selzner M, Odermatt B, Tian Y, Van Rooijen N, Clavien PA (2003) ICAM-1 triggers liver regeneration through leukocyte recruitment and Kupffer cell-dependent release of TNFalpha/IL-6 in mice. Gastroenterology 124:692-700

93. Fausto N, Campbell JS, Riehle KJ (2006) Liver regeneration. Hepatology 43:S45-53

94. Sakaida I, Terai S, Yamamoto N, Aoyama K, Ishikawa T, Nishina H, Okita K (2004) Transplantation of bone marrow cells reduces CCl4-induced liver fibrosis in mice. Hepatology 40:1304-1311 